\title{
PENGEMBANGAN MEDIA PEMBELAJARAN POSBUK (POSTER BUKU) UNTUK MENINGKATKAN PEMAHAMAN KONSEP SISWA KELAS X PADA MATERI HUKUM NEWTON
}

\author{
Nur Ramadhan ${ }^{1 *}$, Linda Sekar Utami², Johri Sabaryati ${ }^{3}$ \\ ${ }^{1 *}$ Mahasiswa Sarjana Progran Studi Pendidikan Fisika Universitas Muhammadiyah Mataram \\ ${ }^{283}$ Dosen Progran Studi Pendidikan Fisika Universitas Muhammadiyah Mataram \\ Corresponding author : \\ E-mail: (joyafarashy@gmail.com)
}

Diterima 25 Oktober 2017, Disetujui 8 November 2017

\begin{abstract}
ABSTRAK
Tujuan dari penelitian ini untuk mengembangkan PosBuk (Poster Buku) pada pokok bahasan hukum newton, untuk meningkatkan pemahaman konsep siswa. Penelitian ini menggunakan metode research and development ( $R$ \& D). Sebagai subjek dalam penelitian ini adalah siswa SMA Muhamadiyah Mataram Kelas X. Model pengembangan yang digunakan adalah Dick \& Carey yang terdiri dari 10 langkah yang harus diikuti untuk menghasilkan produk berupa PosBuk (Poster Buku). Data diperoleh melalui angket dan dokumentasi. Teknik analisis data yang digunakan adalah mengunakan rumus $\mathrm{N}$-gain untuk mengukur pemahaman konsep siswa. Analisis data yang digunakan adalah kualitatif ke kuantitatif untuk mengukur pemahaman konsep siswa. Hasil penelitian menunjukkan bahwa media pembelajaran yang dikembangkan berupa PosBuk (Poster Buku) memiliki kriteria yang sangat baik berdasarkan penilaian dari ahli dan praktisi. Media PosBuk (Poster Buku) yang dikembangkan juga memiliki kriteria yang sangat baik untuk meningkatkan pemahaman konsep siswa dengan nilai gain 0,679. Dengan ketuntasan belajar klasikal diperoleh peningkatan $84,37 \%$. Berdasarkan hasil dari penelitian ini dapat disimpulkan bahwa media pembelajaran PosBuk (Poster Buku) dapat meningkatkan pemahaman konsep belajar siswa kelas X MAN 1 Mataram.
\end{abstract}

Kata Kunci: Pengembangan Media Pembelajaran Fisika, PosBuk (Poster Buku), Pemahaman Konsep

\section{PENDAHULUAN}

Fisika merupakan pelajaran yang terurut, bertingkat dan berkelanjutan. Artinya materi yang diberikan kepada siswa adalah konsep-konsep dasar yang merupakan fondasi dalam penyampaian konsep selanjutnya. Keberhasilan pemahaman konsep fisika pada siswa menjadi pembuka jalan dalam penyampaian konsep-konsep fisika selanjutnya sehingga siswa akan lebih mudah dalam memahami konsep-konsep fisika pada materi selanjutnya. Selain itu, jika siswa memahami konsep dengan baik maka siswa dapat menyelesaikan berbagai variasi soal fisika dan dapat mempermudah siswa dalam menyelesaikan masalah fisika yang berkaitan dengan kehidupan seharihari.

Permasalahan yang sering kita temukan dalam kegiatan belajar mengajar (KBM) khususnya pembelajaran fisika yaitu guru yang sangat berperan aktif dalam menyampaikan pelajaran, sehingga siswa hanya menerima pelajaran tanpa ada pengalaman dari siswa itu sendiri, siswa kurang didorong untuk mengembangkan kemampuan berpikir. Proses pembelajaran di dalam kelas diarahkan kepada kemampuan anak untuk menghafal informasi, otak anak dipaksa untuk mengingat dan menimbun berbagai informasi tanpa dituntut untuk memahami konsep informasi yang diingatnya itu sehingga pemahaman konsep siswa kurang optimal.

Mengingat fisika memiliki beberapa unit yang satu sama lain saling berhubungan, maka yang penting dalam belajar fisika adalah bagaimana kemampuan seseorang dalam memahami konsep fisika. Kenyataan di lapangan siswa hanya menghafal rumus yang sudah ada dan kurang mampu mengaitkan asal mula rumus tersebut dengan konsep yang dimiliki. Telah diketahui bahwa semua 
materi fisika yang ada dalam sekolah mengandung aspek pemahaman konsep, karena kemampuan mendasar dalam belajar fisika adalah memahami konsep terlebih dahulu. Secara umum peserta didik sering mengalami kesulitan dalam kegiatan pembelajaran fisika, di antaranya adalah kesulitan menghitung cepat, kemampuan logika, keterampilan menulis atau mengambar dan rasa malas belajar fisika. Ini disebabkan karena kurangnya peserta didik dalam memahami konsep-konsep yang ada dalam pelajaran fisika.

Berdasarkan permasalahan yang sering timbul disekolah dengan penerapan suatu media pembelajaran baru yang sekaligus dapat digunakan sebagai media belajar peserta didik, akan menjadi solusi terbaik untuk meningkatkan pemahaman konsep belajar siswa. Adapun media pembelajaran yang dapat digunakan adalah media PosBuk (Poster Buku). Pembelajaran PosBuk (Poster Buku) adalah suatu media pembelajaran yang digunakan oleh pengajar untuk menyampaikan materi kepada peserta didik dalam bentuk gambar-gambar, warna dan agar dapat menarik perhatian peserta didik dalam proses belajar mengajar dalam bentuk buku.

Media poster sebelumnya sudah diterapkan oleh peneliti lain dalam jurnal Maiyena, (2013) tentang Pengembangan Media Poster Berbasis Pendidikan Karakter untuk Materi Global Warming dimana hasil penelitian tersebut yaitu hasil uji coba dalam 1 kelas terhadap media poster berkisar $74 \%$ sampai $84,9 \%$. Dengan demikian media poster berbasis pendidikan karakter menurut mahasiswa sudah sangat praktis atau sangat baik.

Selain itu juga pada penelitian Jannah (2016) berdasarkan uji coba yang telah dilakukan terhadap perorangan, kelompok kecil dan kelompok besar didapatkan hasil rata-rata $85,39 \%$. Oleh karena itu peneliti mencoba menerapkan media pembelajaran Poster dalam bentuk buku untuk peserta didik di MAN 1 Mataram pada materi Hukum Newton.

Berdasarkan hal tersebut bahwa pembelajaran fisika dengan memanfaatkan media pembelajaran berupa PosBuk dapat meningkatkan pemahaman konsep pada peserta didik. Sehingga peneliti melakukan penelitian yang berjudul " Pengembangan
Media Pembelajaran PosBuk (Poster Buku) Untuk Meningkatkan Pemahaman Konsep Siswa Kelas X Pada Materi Hukum Newton". Dengan harapan peserta didik lebih aktif dalam proses pembelajaran serta dapat menguasai konsep-konsep materi fisika dengan baik melalui media pembelajaran PosBuk (Poster Buku).

\section{METODE PENGEMBANGAN \\ Jenis Penelitian}

Jenis penelitian ini adalah penelitian pengembangan dengan menggunakan metode (Reseach \& Development). Reseach \& Development adalah metode pengembangan yang digunakan untuk menghasilkan produk. Model pengembangan merupakan cara yang digunakan untuk menentukan, mengembangkan dan menguji suatu produk berdasarkan prosedur yang sistematis, sehingga produk yang dihasilkan memiliki nilai ilmiah yang tinggi dan dapat dipercaya. Model penelitian dan penelitian pengembangan adalah metode penelitian yang digunakan untuk menghasilkan atau mengembangkan produk tertentu, dan menguji keektifan produk tersebut (Sugiyono, 2014: 297). Produk yang dihasilkan dalam penelitian pengembangan ini adalah Poster yang berbentuk buku atau secara singkatnya PosBuk (Poster buku). Penelitian pengembangan merupakan kegiatan mengembangkan suatu produk baru atau menyempurnakan produk yang telah ada.

Desain penelitian ini menggunakan satu kelas buat sampel sebagai kelas uji coba (One Group pre- Test and Post-test Design). Teknik pengumpulan data pada penelitian ini adalah angket dan dokumentasi. Angket digunakan untuk mengumpulkan data tentang kelayakan media pembelajaran yang dibuat dan akan di jawab oleh responden yang terkait pembelajaran antara lain: ahli materi, ahli media dan siswa sebagai pengguna media pembelajaran PosBuk (Poster Buku).

\section{Lokasi dan Waktu penelitian}

\section{Lokasi Penelitian}

Penelitian ini akan dilaksanakan di sekolah menengah atas MAN 1 Mataram, melibatkan siswa kelas $\mathrm{X}$.

\section{Waktu Penelitian}


Penelitian ini akan dilaksanakan pada bulan Juli 2017 pada siswa MAN 1 Mataram kelas $X$.

\section{Model Pengembangan}

Model pengembangan diartikan sebagai proses desain konseptual dalam upaya peningkatan fungsi dari model yang telah ada sebelumnya, melalui penambahan komponen pembelajaran yang dianggap dapat meningkatkan kualitas pencapaian tujuan (Sugiarta, 2007:11). Model pengembangan yang digunakan dalam penelitian ini adalah Dick \& Cary yaitu menggariskan langkahlangkah untuk menghasilkan produk berupa PosBuk fisika yaitu: (1) Mendefinisikan tujuan untuk produk, (2) Analisis instruksional, (3) Mengidentifikasi keterampilan dan sikap siswa,

Menerjemahkan kebutuhan dan tujuan pembelajaran, (5) Instrumen penilaian dikembangkan, (6) Strategi pembelajaran dikembangkan, (7) Mengembangkan dan melibatkan materi pembelajaran (8) Merencanakan dan mengembangkan evaluasi vormatif (9) Melakukan revisi terhadap program pembelajaran dan (10) mengembangkan dan merancang evaluasi sumatif (Emzir, 2014:276).

\section{Langkah-Langkah Penelitian}

Langkah-langkah penelitian dan pengembangan PosBuk (Poster Buku) sebagai berikut (Sugiyono, 2014: 298):

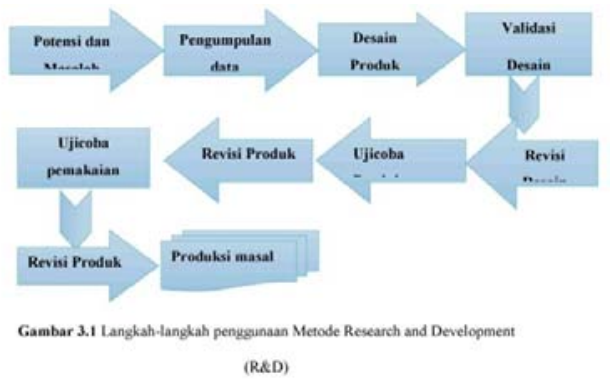

Penelitian ini dilakukan sampai pada tahap uji coba produk karena keterbatasan waktu dan dana. Media dikatakan valid apabila telah divalidasi oleh ahli dan diuji kefektifannya oleh peneliti dengan adanya pemahaman konsep belajar pada diri masing-masing siswa.

\section{Metode Penelitian Tahap 1}

\section{Potensi dan Masalah}

Penelitian dapat berangkat dari potensi dan masalah yang ada. Potensi adalah sesuatu yang bila didayagunakan akan memiliki nilai tambah (Sugiyono, 2014: 298). Potensi yang ditemukan dalam penelitian ini adalah buku dalam kegiatan pembelajaran. Masalah dalam penelitian ini adalah kurangnya pemahaman konsep siswa kelas $X$ MAN 1 Mataram terhadap mata pelajaran FISIKA.

Mengumpulkan Data

Langkah yang diambil setelah ditemukan potensi dan masalah dalam penelitian ini adalah mengumpulkan informasi. Informasi dapat dilakukan sebagai bahan untuk perencanaan produk tertentu. Pada penelitian ini, peneliti akan menghasilkan dan mengembangkan produk berupa PosBuk yang berbentuk buku. Berdasarkan hasil pengumpulan informasi yang telah dilakukan disekolah, ditemukan permasalahan adalah rendahnya pemahaman konsep pada siswa. Pemicu salah satunya adalah kurangnya media pembelajaran yaitu buku pegangan siswa. Oleh karena itu, peneliti akan mengembangkan media pembelajaran berupa PosBuk (Poster buku) yang menarik dan sangat praktis di gunakan.

\section{Desain Produk}

Desain produk dalam penelitian ini diwujudkan dalam bentuk gambar dan bagan. Dalam penelitian ini, komponen desain produk adalah:

1. PosBuk memiliki 1 edisi, yaitu untuk edisinya untuk materi hukum newton

2. PosBuk ukurannya lumayan besar dan bisa di bawa kemana-mana.

3. Susunan dari segi PosBuknya yaitu materi atau berita yang singkat seperti poster umumnya dan memiliki redaksi.

4. Susunan dari segi bukunya memiliki daftar isi dan daftar pustaka.

\section{Validasi Produk}

Validasi desain atau produk adalah proses kegiatan untuk menilai apakah rancangan produk dalam hal ini sistem kerja baru secara rasional akan lebih efektif dari yang lama atau tidak. Dikatakan secara rasional, karena validasi disini masih bersifat penilaian berdasarkan pemikiran, rasional, belum fakta lapangan (Sugiyono, 2014: 302).

Validasi produk dapat dilakukan dengan cara menghadirkan beberapa pakar atau tenaga ahli yang sudah berpengalaman untuk menilai produk baru yang dirancang tersebut, sehingga 
selanjutnya dapat diketahui kelemahan dan kekuatannya. Validasi desain dapat dilakukan dalam forum diskusi. Sebelum diskusi peneliti mempresentasikan proses penelitian sampai ditemukan desain tersebut.

Kegiatan validasi isi ini akan dilakukan oleh ahli media pembelajaran dan ahli materi Fisika dengan cara mengisi instrumen berupa angket dan memberi kritik atau saran terhadap produk pengembangan. Validasi isi dilakukan agar mengetahui kelayakan isi produk yang dikembangkan. Validasi ahli pada pengembangan PosBuk merupakan tiga orang dosen dan satu orang guru Fisika MAN 1 Mataram. Kriteria dosen diantaranya minimal menempuh pendidikan S2 dan guru di MAN 1 Mataram minimal menempuh pendidikan $\mathrm{S} 1$ dan berpengalaman mengajar materi Hukum Newton

\section{Instrumen Pengumpulan Data}

Instrumen penelitian digunakan untuk mengukur nilai variabel yang akan diteliti. Dengan demikian jumlah instrumen yang akan digunakan untuk penelitian akan tergantung pada jumlah variabel yang diteliti (Sugiyono, 2014: 92). Secara spesifikasi fenomena yang terjadi disebut variabel penelitian. Instrument yang digunakan dalam penelitian ini lembar angket pemahaman konsep (Kuisioner). Kuisioner merupakan teknik pengumpulan data yang dilakukan dengan cara memberi seperangkat pertanyaan atau pernyataan tertulis kepada responden untuk menjawabnya. Kuisioner merupakan teknik pengumpulan data yang efisien bila peneliti tahu dengan pasti variabel yang akan diukur dan tahu apa yang bisa diharapkan dari responden (Sugiyono, 2014: 142).

Angket validasi media pembelajaran memiliki gradulasi pernyataan sangat positif sampai sangat negatif yang digunakan untuk mengukur indikator program yang berkaitan dengan kriteria pendidikan, tampilan dan kualitas teknis (Arsyad, 2015:219).

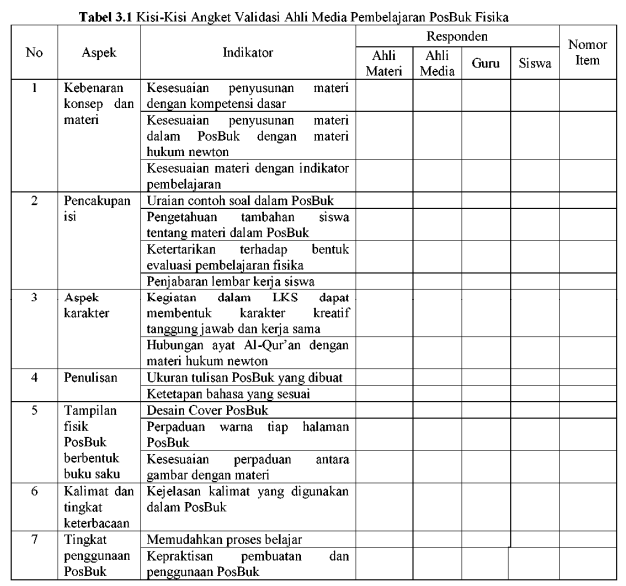

Skala pengukuran yang digunakan untuk mengukur validasi produk dan pemahaman konsep siswa adalah skala likert yang memiliki gradulasi penilaian dari sangat positif sampai sangat negatif. Teknik skorsing dalam skala likert adalah sebagai berikut (Sugiyono, 2014:94) :

Tabel 3.2 Skala Likert
\begin{tabular}{|l|l|c|}
\hline \multicolumn{1}{|c|}{ Kriteria } & Skor \\
\hline 1 & Sangat setuju (Sangat Positif) & 5 \\
\hline 2 & Setuju (Positif) & 4 \\
\hline 3 & Kurang setuju (Negatif) & 3 \\
\hline 4 & Tidak setuju (sangat negatif) & 2 \\
\hline 5 & Sangat tidak setuju (sangat negatif) & 1 \\
\hline
\end{tabular}

\section{Instrumen Tes Uraian}

Tes Uraian (Esai) adalah sejenis tes kemajuan belajar yang memerlukan jawaban yang bersifat pembahasan atau uraian kata-kata (Arikunto, 2015: 177). Tes uraian ini digunakan untuk mengetahui pemahaman konsep fisika pada materi Hukum Newton. Tes ini dilaksanakan sebelum dan setelah diberikan pembelajaran untuk mengetahui seberapa besar pemahaman konsep fisika pada siswa. 
Tabel 3.2 Kisi-kisi instrumen soal pemahaman konsep belajar siswa

\begin{tabular}{|c|c|c|c|c|c|c|c|c|c|}
\hline \multirow[t]{2}{*}{ No } & \multirow[t]{2}{*}{ Indikator } & \multicolumn{6}{|c|}{ Aspek kognitif } & \multicolumn{2}{|c|}{ Proporsi } \\
\hline & & $\mathrm{C} 1$ & $\mathrm{C} 2$ & $\mathrm{C} 3$ & $\mathrm{C} 4$ & $\mathrm{C5}$ & C6 & $\Sigma$ & $\%$ \\
\hline 1 & $\begin{array}{l}\text { Menyebutkan bunyi } \\
\text { dari Hukum I, II, dan } \\
\text { III Newton }\end{array}$ & $\sqrt{ }$ & & & & & & & \\
\hline 2 & $\begin{array}{lr}\text { Tuliskan aplikasi } \\
\text { hukum I, II dan III } \\
\text { newton yang dapat } \\
\text { diterapkan } & \text { dalam } \\
\text { kehidupan } & \text { sehari- } \\
\text { hari } & \\
\end{array}$ & & $\sqrt{ }$ & & & & & & \\
\hline 3 & $\begin{array}{l}\text { Menjelaskan } \\
\text { pengertian } 3 \text { hukum } \\
\text { newton }\end{array}$ & $\sqrt{ }$ & & & & & & & \\
\hline 4 & $\begin{array}{lr}\text { Sebuah } & \text { balok } \\
\text { bermassa } 5 \mathrm{~kg} \text { (berat } \\
\mathrm{w}=50 \mathrm{~N} \text { ) } \\
\text { digantung dengan } \\
\text { tali dan diikatkan } \\
\text { pada atap. Jika balok } \\
\text { diam r maka } \\
\text { berapakah tegangan } \\
\text { talinya? }\end{array}$ & & & & $\sqrt{ }$ & & & & \\
\hline & Jumlah & & & & & & & & \\
\hline
\end{tabular}

Keterangan :

$\begin{array}{ll}\text { C1 } & \text { : Hafalan/ingatan } \\ \text { C6 } & \text { : Evaluasi } \\ \text { C2 } & \text { : Pemahaman } \\ \Sigma & : \text { Soal yang valid } \\ \text { C3 } & \text { : Penerapan } \\ \text { C4 } & \text { : Analisis } \\ \text { C5 } & \text { : Sintesis }\end{array}$

\section{Perancangan Prosedur Penelitian}

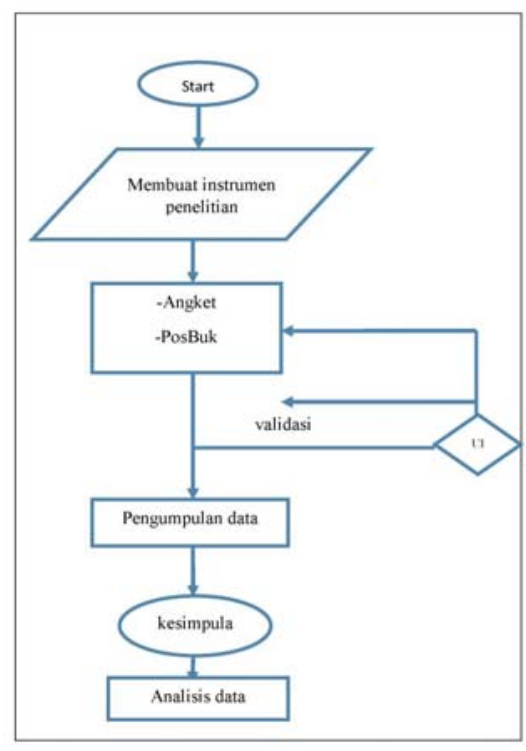

Gambar 3.2 Flouwchart Rancangan Penelitian

\section{Rancangan Eksperimen Untuk Menguji Subjek Uji Coba \\ Subjek uji coba terdiri atas ahli} bidang isi atau materi, ahli bidang perancangan produk dan sasaran pemakai produk. Dimana subjek uji coba untuk ahli materi dan perancangan atau media berfungsi sebagai validator yaitu dengan mengisi instrument berupa angket dan memberi kritik atau saran terhadap produk pengembangan. Validasi dilakukan agar mengetahui kelayakan isi produk yang dikembangkan.

Teknik Pengumpulan data

Teknik Analisis Data Angket Validasi Produk

Teknik analisis data angket validasi produk pada penelitian ini dilakukan untuk mengetahui kelayakan produk yang dikembangkan sebelum digunakan. Dimana data yang diperoleh melalui penilaian ahli media atau praktisi kemudian akan dijumlahkan dan total skor yang diperoleh dikonversikan menjadi data kualitatif dengan skala lima (Azwar, 2015:163).

Tabel 3.4 Konversi Data Kuantitatif Ke Kualitatif Dengan Skala Lima

\begin{tabular}{|l|l|c|}
\hline \multicolumn{1}{|c|}{ Interval } & \multicolumn{1}{c|}{ Kriteria } & Skor \\
\hline$(M+1,50 \mathrm{~s})<\mathrm{X}$ & Sangat baik & A \\
\hline$(\mathrm{M}+0,50 \mathrm{~s})<\mathrm{X} \leq(\mathrm{M}+1,50 \mathrm{~s})$ & Baik & B \\
\hline$(\mathrm{M}-0,50 \mathrm{~s})<\mathrm{X} \leq(\mathrm{M}+0,50 \mathrm{~s})$ & Cukup baik & C \\
\hline$(\mathrm{M}-1,50 \mathrm{~s})<\mathrm{X} \leq(\mathrm{M}-0,50 \mathrm{~s})$ & Kurang baik & D \\
\hline $\mathrm{X} \leq(\mathrm{M}-1,50 \mathrm{~s})$ & Tidak baik & E \\
\hline
\end{tabular}

Keterangan:

$\mathrm{X}=$ Total skor responden

$\mathrm{M}=$ Mean ideal, $1 / 2$ (skor maksimal ideal+skor minimal ideal)

$\mathrm{s}=$ Simpangan baku ideal, 1/6 (skor maksimal ideal-skor minimal ideal)

Teknik Analisis Data Pemahaman Konsep

Analisis data dilakukan setelah proses pengumpulan data, dimana penelitian ini lebih menitik beratkan pada pengembangan PosBuk (Poster Buku) fisika untuk meningkatkan pemahaman konsep belajar siswa kelas $X$ MAN 1 Mataram materi hukum newton. Instrument soal uraian yang digunakan harus dilakukan uji validasi dan uji releabilitas. Dimana teknik analisis data untuk percobaan ini adalah teknik instrument soal uraian dan dokumentasi.

\section{Metode Penelitian Tahap II} Uji Validitas

Untuk menghitung banyaknya pernyataan yang valid atau tidaknya dapat dihitung nilai validitas dengan rumus Pearson Product Moment adalah (Arikunto, $2015: 87)$ :

$r_{x y}=\frac{n \sum X_{i} Y_{i}-\left(\sum X_{i}\right) \cdot\left(\sum Y_{i}\right)}{\sqrt{\left\{n \sum X_{i}^{2}-\left(\sum X_{i}\right)^{2}\right\} \cdot\left\{n \cdot \sum Y_{i}^{2}-\left(\sum Y_{i}\right)^{2}\right\}}}$ 
Keterangan:

$r_{\text {hitung }}=$ Koefisien korelasi antara variabel $\mathrm{X}$ dan variabel $\mathrm{Y}$, dua variable yang dikorelasikan.

$\mathrm{X}_{\mathrm{i}}=$ Jumlah skor item

$Y_{i}=$ Jumah skor total (seluruh item)

$\mathrm{n}=$ Jumlah responden

Uji Reliabilitas

Uji reliabilitas dilakukan untuk mengetahui reliabilitas instrumen tes uraian yang digunakan. Langkah-langkah mencari nilai reliabilitas sebagai berikut (Arikunto, 2015: 123):

$$
r_{11}=\left(\frac{n}{n-1}\right)\left(1-\frac{\sum \sigma_{i}^{2}}{\sigma_{i}^{2}}\right)
$$

Keterangan:

$r_{11}=$ Nilai reliabilitas

$\sum \sigma_{i}^{2}=$ Jumlah varians skor tiap-tiap item

$\sigma_{i}^{2}=$ Varians total

$n=$ Jumlah item

Selain itu perlu dicari nilai varians untuk menentukan reliabilitas instrumen soal pemahaman konsep siswa menggunakan rumus sebagai berikut (Arikunto, 2015: 123):

$$
\sigma^{2}=\frac{\sum X^{2}-\frac{\left(\sum X\right)^{2}}{N}}{N}
$$

Keterangan:

$$
\begin{array}{ll}
\sigma^{2} & =\text { Varians skor tiap-tiap item } \\
\sum X^{2} & =\text { Jumlah kuadrat item Xi }
\end{array}
$$

$\left(\sum X\right)^{2}=$ Jumlah item $X i$ dikuadratka

$$
\mathrm{N} \quad=\text { Jumlah responden }
$$

Nilai korelasi yang diperoleh dikonsultasikan ke tabel Product Moment dengan taraf $a=0,05$ atau $a=0,01$. Jika harga $r_{\text {hitung }}>r_{\text {tabel }}$ maka reliabel dan harga rhitung $<$ rtabel berarti tidak reliabel.

\section{Tingkat Kesukaran}

Untuk mengetahui tingkat

kesukaran dari suautu soal dapat dihitung dengan menggunakan persamaan (Salmina \& Adyansyah, 2017:43) :

$$
T K=\frac{\bar{x}}{\text { Xmaks }}
$$

Keterangan

$\boldsymbol{T} \boldsymbol{K}=$ Tingkat kesukaran

$\overline{\boldsymbol{X}}=$ Skor rata-rata peserta didikuntuk satu butir soal
Xmaks = Skor maksimum yang telah ditetapkan sesuia tingkat kesukarannya.

Tabel 3. 5 Interpretasi Tingkat Kesukaran

\begin{tabular}{|l|l|c|}
\hline No & Indeks Tingkat Kesukaran & Kriteria \\
\hline 1 & KD 0,00 sampai 0,30 & Sukar \\
\hline 2 & KD 0,32 sampai 0,71 & Sedang \\
\hline 3 & KD 0,71 sampai 1,00 & Mudah \\
\hline \multicolumn{2}{|c|}{ (Sumber: Arikunto, 2015: 223) } \\
\hline
\end{tabular}

\section{Daya Pembeda}

\begin{tabular}{lllr}
\multicolumn{1}{c}{ Daya } & pembeda & soal & adalah \\
kemampuan & sesuatu & soal & untuk \\
membedakan & antara & siswa & yang
\end{tabular} berkemampuan tinggi dengan siswa yang berkemampuan rendah. Untuk menghitung daya beda saol menggunakan rumus (Salmina \& Adyansyah, 2017:43) :

$$
D B=\frac{\bar{x}_{A}-\bar{x}_{B}}{\text { Xmaks }}
$$

Keterangan:

$D B=$ Daya pembeda

$\overline{\boldsymbol{x}}_{A}=$ Skor rata rata siswa berkemampuan tinggi

$\overline{\boldsymbol{x}}_{B}=$ Skor rata rata siswa berkemampuan rendah

$\boldsymbol{X}_{\text {ma As }}=$ Skor maksimum yang ditetapkan.

Tabel 3.6 Klasifikasi Daya Pembeda

\begin{tabular}{|c|c|c|}
\hline No & Daya Pembeda & Kriteria \\
\hline 1 & $D=0,00$ sampai 0,20 & Jelek \\
\hline 2 & $D=0,21$ sampai 0,40 & Cukup \\
\hline 3 & $D=0,41$ sampai 0,70 & Baik \\
\hline 4 & $D=0,71$ sampai 1,00 & Baik sekali \\
\hline 5 & $D=$ negatif, & Semuanya tidak baik. \\
\hline \multicolumn{2}{|c|}{} \\
(Sumber: Arikunto, 2015: 232)
\end{tabular}

\section{Uji Keefektifan}

Uji keefektifan untuk mengetahui peningkatan hasil belajar dan pemahaman konsep siswa setelah menggunkan alat peraga.

\section{Uji Gain}

Untuk melihat besarnya peningkatan pemahaman konsep siswa digunakan uji gain dengan persamaan :

$$
\text { gain }=\frac{S_{\text {post }}-S_{\text {pre }}}{100-S_{\text {pre }}}
$$

Keterangan:

g(gain) = gain

Spre = skor awal

Spost = skor akhir

Data hasil perhitungan instrumen soal uraian sebelum menggunakan PosBuk 
(Poster buku) dan sesudah menggunakan PosBuk (Poster buku) siswa kemudian akan diiterpretasikan dengan menggunakan gain standar sebagai berikut (Hake, 1998: 65) :

Tabel 3.7 Nilai Indeks Gain Standar

\begin{tabular}{|c|c|}
\hline Nilai gain standar & Keterangan \\
\hline$\geq 0,7$ & Tinggi \\
\hline $0,7 \geq g \geq 0,3$ & Sedang \\
\hline$\leq 0,3$ & Rendah \\
\hline
\end{tabular}

Apabila media pembelajaran dapat meningkatkan pemahaman konsep siswa, maka media pembelajaran dikatakan telah teruji keefektifannya.

Untuk mengetahui pengaruh
penggunaan media

$$
t=\frac{M d}{\sqrt{\frac{\sum X^{2} d}{N(N-a)}}}
$$

(Sumber: Arikunto, 2006:306-307)

Dengan :

Md = Mean dari perbedaan pretest dan post test

$X d=$ Devisi masing-masing subjek $(\mathrm{d}-\mathrm{Md})$

$\sum \mathrm{x}^{2} \mathrm{~d}=$ Jumlah kuadrat revisi

$\mathrm{N}=$ Subjek pada sampel

$\mathrm{d} . \mathrm{b}=$ Ditentukan dengan $\mathrm{N}-1$

\section{Ketuntasan Belajar Klasikal}

Untuk mengukur ketuntasan belajar secara klasikal digunakan persamaan:

$\% P=\frac{\sum \text { siswa mendapat nilai } \geq 60}{\sum \text { siswa }} \times 10 \% \%$

Ketuntasan belajar klasikal dinyatakan berhasil jika presentase siswa yang tuntas atau nilai lebih besar atau sama dengan $60 \%$ adalah lebih besar atau sama dengan $85 \%$ dari seluruh siswa di kelas (Sampudi \& Morik 2009: 30).

\section{HASIL DAN PEMBAHASAN \\ Hasil Penelitian \\ Metode Penelitian Tahap I \\ Potensi dan Masalah}

Berdasarkan hasil wawancara dengan guru Fisika di MAN 1 Mataram, ditemukan adanya permasalahan yang mengakibatkan kurangnya pemahaman konsep belajar yaitu metode pengajaran yang digunakan oleh guru kurang efektif, kurangnya menggunakan media pembelajaran sebagai media tambahan untuk menarik minat belajar siswa, dan tidak tersedianya buku pelajaran bagi masing-masing siswa sebagai pegangan untuk belajar di rumah.

Oleh karena tidak tersedianya buku pelajaran bagi masing-masing siswa sehingga setiap pelajaran wajib mencatat untuk mengejar materi. Permasalahan tersebut harus segera diatasi dan diperlukan suatu cara, bukan hanya sekedar strategi dan model pembelajaran yang cocok digunakan oleh guru selama proses pembelajaran, namun yang paling penting adalah media pembelajaran tambahan yang dapat membantu siswa dalam belajar sehingga tidak perlu mencatat semua materi setiap pertemuan. Salah satu media pembelajaran yang tepat dan sesuai untuk meningkatkan pemahaman konsep belajar siswa adalah media pembelajaran PosBuk (Poster Buku). Mengumpulkan Informasi

Pengumpulan informasi dilakukan dengan observasi sehingga diperoleh informasi bahwa siswa memiliki pemahaman konsep belajar siswa kelas $X$ Unggulan di MAN 1 Mataram masih kurang. Observasi dilakukan dengan menanyakan permasalahan pada guru yang mengajar dan melakukan pengamatan dalam kegiatan pembelajaran di kelas.

\section{Desain Produk}

Berdasarkan kondisi yang telah ada di sekolah, dapat diketahui bahwa dalam pelaksanaan pembelajaran media buku yang praktis sangat dibutuhkan oleh siswa. Buku pelajaran disekolah yang digunakan guru untuk mengajar masih kurang membantu untuk meningkatkan pemahaman konsep belajar. Buku pelajaran yang digunakan dalam pembelajaran memiliki pembahasan materi yang panjang sehingga siswa cepat merasa bosan dalam membacanya kemudian sulit memahami konsep dalam buku tersebut. Serta buku pelajaran yang digunakan tersebut tidak memiliki pendidikan berkarakter yang bertujuan untuk meningkatkan pemahaman konsep belajar siswa. Dengan demikian, maka diperlukan buku yang mampu meningkatkan pemahaman konsep belajar pada siswa. 
Dengan demikian media PosBuk (Poster Buku) yang dikembangkan oleh peneliti merupakan salah satu media yang memiliki kelebihan antara lain dapat meningkatkan pemahaman konsep siswa selama proses belajar mengajar, memiliki variasi warna serta ilustrasi gambar yang merupakan media yang dapat meningkatkan kualitas pembelajaran. Selain itu ukurannya yang mudah untuk dibawa kemana-mana menjadi sebuah gaya tarik PosBuk (Poster Buku) ini.

Media pembelajaran PosBuk (Poster Buku) yang akan dihasilkan yaitu terdiri dari cover PosBuk (Poster Buku), standar kompetensi, kompetensi dasar, materi pembelajaran, contoh soal dan pembahasan serta evaluasi berupa soal uraian dan ukuran tulisan yang mudah dibaca serta konsistensi penomoran pada halamannya. Desain awal produk dikerjakan dengan menggunakan program microsoft office publizer 2008 kemudian dicetak dengan menggunakan kertas Dragg A4 80 gram. Desain awal PosBuk (Poster Buku) dapat dilihat pada lampiran 3.

\section{Hasil Validasi Ahli}

Kegiatan validasi PosBuk (Poster Buku) dilakukan oleh para ahli dengan mengisi angket yang berisi 28 pernyataan yang terdiri dari kriteria pendidikan, kriteria tampilan, dan kualitas teknis. PosBuk (Poster Buku) divalidasi oleh 4 ahli yang dianggap respresentatif dan berpengalaman mengajar materi Fisika dan Ahli media. Angket diisi oleh ahli yang terdiri dari 3 orang dosen dan 1 guru mata pelajaran FISIKA di MAN 1 Mataram. Hasil validasi PosBuk (Poster Buku) adalah sebagai berikut:

\section{Ahli I}

Sesuai dengan hasil pengisian angket dari Bapak Zulkarnain. M.Si selaku ahli I, bahwa item yang paling tinggi diperoleh pada skala 5 (sangat setuju), dimana pengisian angket tertinggi untuk kriteria pendidikan terdapat pada item nomor 4, 6 dan 9. Serta pada kriteria teknis terdapat pada item nomor 7 dan 9 dengan pernyataan pengembangan media pembelajaran PosBuk (Poster Buku) dapat dipadukan dengan berbagai metode ataupun model pembelajaran dan pengembanagan media pembelajaran PosBuk (Poster Buku) ini sangat praktis dan mudah dibawa kemana-mana.
Berdasarkan hasil pengolahan data menggunakan interval diperoleh untuk kualitas kriteria pendidikan sangat baik, kriteria tampilan baik dan kriteria teknis baik,.

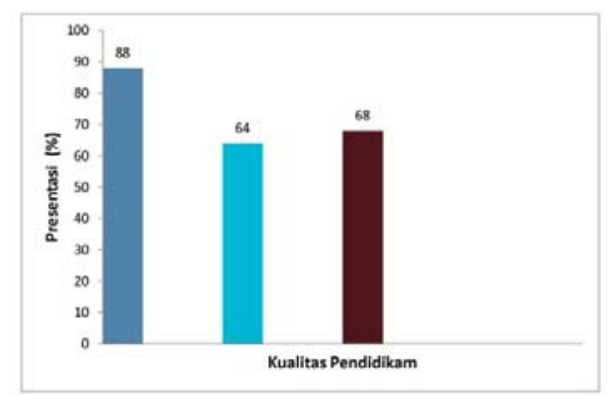

Grafik 4.1 Presentasi Validasi Produk Ahli I

Sehingga disimpulkan bahwa
PosBuk (Poster Buku) layak untuk
digunakan dan ahli I menyarankan revisi
pada gambar cover dan mencari gambar
yang berkaitan dengan materi Hukum I
Newton

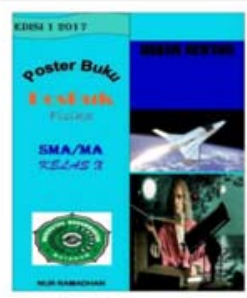
Gambar 4.1 Cover yang belum di

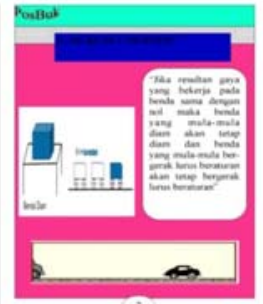
Gambar 4.2 Perpaduan gambar dar

\section{Ahli II}

Pengisian angket dari Islahudin, M.Pfis selaku ahli II diperoleh pengisian angket tertinggi berada di skala 4 ( setuju) yaitu pada kriteria pendidikan berada pada no item $1,2,4,6$, dan 8 , kriteria tampilan berada pada item no 1 sampai 9 dan kriteria teknis berada pada no item 1, 2, 3, $5,6,7,8,9$. Sedangkan kriteria terendah pada skala 2 (tidak setuju) yaitu pada kriteria teknis pada nomor item 4 dengan pernyataan pengembangan media pembelajaran PosBuk ini dalam pembuatannya sama sekali tidak membutuhkan tenaga ahli. Pengolahan datanya menggunakan interval berada pada kriteria untuk kualitas pendidikan sangat baik, tampilan baik dan teknis sangat baik. 

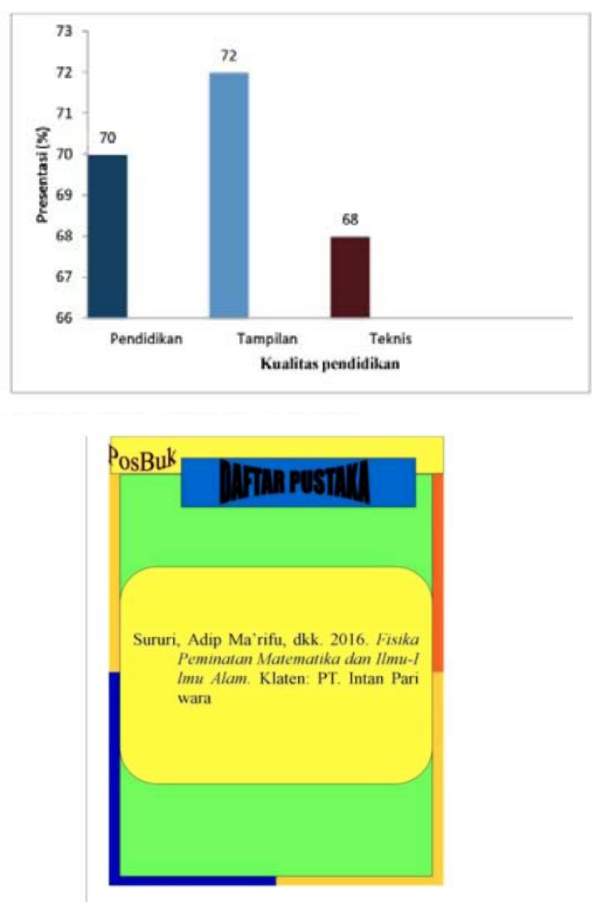

Gambar 4.3 daftar pustaka harus banyak referensi

\section{Ahli III}

Pengisian angket dari pak Nanang Rahman, M.Pd selaku ahli III diperoleh pengisian angket tertinggi berada di kriteria pendidikan pada item nomor 4 , kriteria tampilan item nomor 1,2,3,4 dan 5, kriteria teknis item nomor 7,8 dan 9 sama-sama berada pada skala 5 yaitu sangat setuju. Sedangkan pengisian angket terendah ratarata berada pada skala 2 yaitu tidak setuju yang berada pada kriteria teknis item nomor 6. Dari hasil pengisian angket ahli III untuk kualitas pendidikan, kualitas tampilan dan kualitas teknis diperoleh hasil pengolahan datanya menggunakan interval berada pada kriteria baik, sangat baik, dan baik.

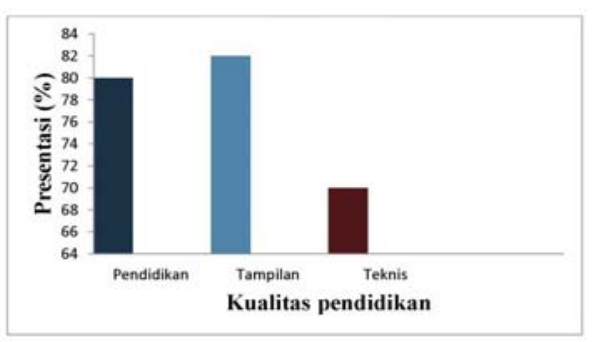

Grafik 4.2 Presentasi validasi produk ahli III
Dan Ahli III merekomendasikan perbaikkan revisi pada bagian tampilan gambar dan tulisan yang tidak sesuai.

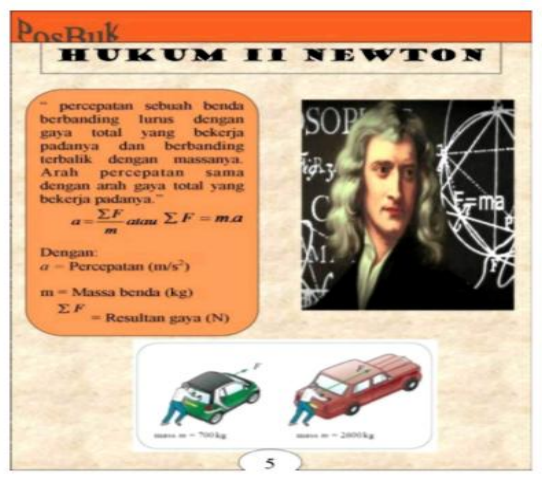

Gambar 4.4 Materi Hukum II Newton

\section{Praktisi}

Hasil pengisian angket dari Syamsul Ihsan, S.Pd selaku praktisi bahwa pengisian angket tertinggi rata-rata berada pada skala 4 (setuju) terdapat pada kriteria pendidikan kriteria tampilan dan kualitas teknis. Sedangkan pengisian angket terendah berada pada skala 3 (kurang setuju) yaitu item 6 dikriteria tampilan dan pada kriteria teknis pada nomor item 6 . Dari hasil pengisian angket praktisi untuk kualitas pendidikan, kualitas tampilan dan kualitas teknis diperoleh hasil pengolahan datanya menggunakan interval berada pada kriteria baik pada kriteria pendidikan baik dan pada kriteria tampilan baik dan kriteria teknis baik dimana berdasarkan praktisi tidak ada revisi pada produk.

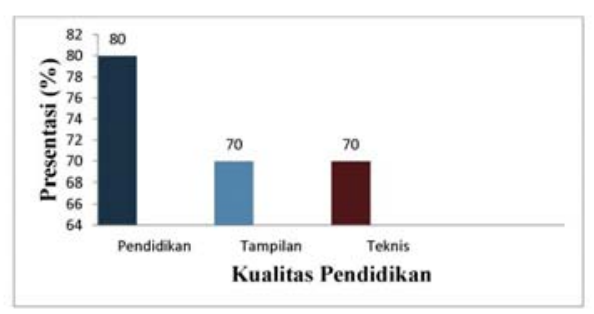

Grafik 4.4 Presentasi validasi produk praktisi

\section{Revisi produk}

Hasil validasi produk yang telah dilakukan menunjukkan bahwa media PosBuk (Poster Buku) harus dilakukan revisi pada bagian tertentu yaitu proporsional gambar, cara penulisan , 
daftar pustaka di tambah dan gambar pada cover harus yang berkaitan sama materi.

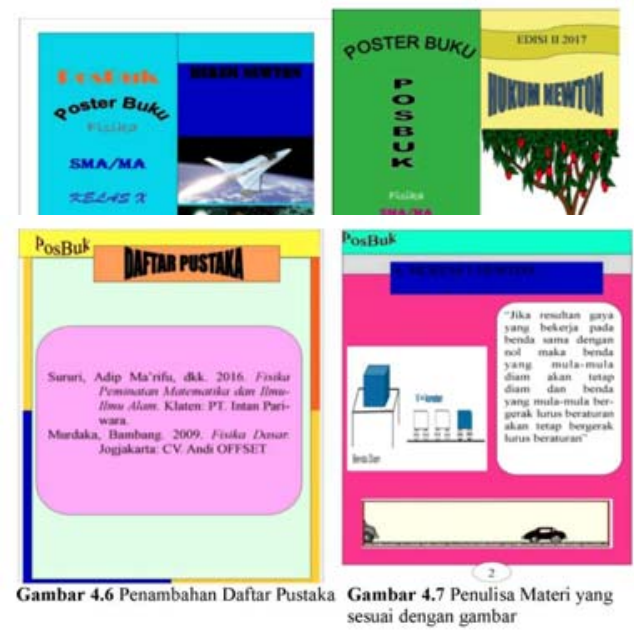

\section{Metode Penelitian Tahap II}

Hasil uji validitas soal

Media pembelajaran PosBuk (Poster

Buku) ini selanjutnya diterapkan untuk meningkatkan pemahaman konsep siswa pada kelompok kecil yaitu kelas $X$ iis unggulan MAN 1 Mataram. Besar pemahaman konsep siswa dapat diukur dengan memberikan soal instrumen kepada siswa. Ada beberapa bentuk aspek pemahaman konsep belajar yang ingin diketahui dalam penelitian ini antara lain, disiplin, tanggung jawab, kreatif, komunikatif dan teliti.

Uji validitas dilakukan pada soal uraian dengan menggunakan persamaan korelasi product moment. Hasil uji validitas soal pemahaman konsep adalah sebagai berikut:

Tabel 4.1 Hasil Perhitungan Validitas Pernyataan soal

\begin{tabular}{|c|c|c|}
\hline Jumlah soal & Valid & Tidak Valid \\
\hline 15 & 8 & 7 \\
\hline
\end{tabular}

Hasil Uji Reliabilitas Soal

Pernyataan pada angket diuji keajengan/keandalannya dengan menggunakan persamaan alpha cronbach. Hasil uji reliabelitas pada pernyataan dapat dilihat pada tabel berikut ini:

Tabel 4.2 Hasil Perhitungan Reliabelitas Pernyataan Soal

\begin{tabular}{|c|c|c|}
\hline Jumlah Pernyataan & Reliabel & Tidak Reliabel \\
\hline 15 & 8 & 7 \\
\hline
\end{tabular}

siswa. Dimana klasifikasi indeks kesukaran menurut Arikunto sebagai berikut:

Tabel 4.3 Interpretasi Tingkat Kesukaran

\begin{tabular}{|c|c|c|}
\hline No & Indeks Tingkat Kesukaran & Kriteria \\
\hline 1 & KD 0,00 sampai 0,30 & Sukar \\
\hline 2 & KD 0,32 sampai 0,71 & Sedang \\
\hline 3 & KD 0,71 sampai 1,00 & Mudah \\
\hline
\end{tabular}

Berdasarkan indeks kesukaran soal terdapat beberapa jumlah soal dengan kriteriannya masing-masing seperti terlihat pada tabel 4.3 dan selengkapnya dapat dilihat pada Lampiran 12 halaman 130.

Tabel 4.4 data tingkat kesukaran soal

\begin{tabular}{|c|c|}
\hline Jumlah soal & Kriteria \\
\hline 5 & Sukar \\
\hline 4 & Sedang \\
\hline 6 & Mudah \\
\hline
\end{tabular}

\section{Uji Daya Beda Soal}

Daya beda soal adalah kemampuan sebuah soal untuk membedakan antara siswa yang pandai (berkemampuan tinggi) dengan siswa yang bodoh (berkemampuan rendah). Berdasarkan hasil uji daya beda soal, maka dapat disimpulkan bahwa soal yang memiliki daya beda buruk sebanyak 2 soal,soal yang memilik daya beda jelek sebanyak 5 soal karena berada pada rentang $0,00-0,20$, soal yang memiliki daya beda cukup berada sebanyak 3 karena berada pada rentang 0,20 - 0,40 dan soal yang memiliki daya beda baik sebanyak 5 soal karena berada pada rentang $0,40-0,70$ lampiran 13 halaman 134.

\section{Hasil uji coba}

Uji kelompok yang digunakan adalah kelas $X$ iis unggulan MAN 1 Mataram dengan menggunakan instrument soal uraian yang sudah valid kemudian diberikan kepada siswa sebelum menggunakan PosBuk (Poster Buku). Kegiatan pengisian soal uraian dapat dilakukan selama 45 menit pada pertemuan pertama sebelum kegiatan pembelajaran dan pada pertemuan terakhir. Masingmasing siswa mendapatkan 1 PosBuk (Poster Buku) .

Perhitungan pemahaman konsep belajar siswa dilakukan pada setiap bentuk aspek atau indikator pemahaman. Hasil Soal uraian kemudian diolah dengan menggunakan langkah-langkah yang dilakukan. Berdasarkan hasil perhitungan dalam penelitian yang dilakukan, maka 
dapat dilihat peningkatan pemahaman konsep belajar pada siswa.

\section{Nilai Gain}

Uji gain dimaksudkan untuk mengetahui hasil perhitungan siswa pretest dan post-test menggunakan PosBuk (Poster buku), yang dimana skor dari perhitungan pre-test instrument soal uraian skor nilai yang didapatkan oleh siswa $42,38 \%$ dan post-testnya mendapatkan skor nilai $81,54 \%$. Setelah mendapatkan nilai pre-test dan post-testnya maka nilai gain yang didapatkan $0,679 \%$. Hal ini menunjukan bahwa siswa mempunyai peningkatan setelah menggunakan PosBuk Poster buku) ketimbang sebelum menggunakan PosBuk (Poster Buku). Nilai Uji-t

Uji-t dilakakukan untuk mengetahui pengaruh penggunaan media yang diberikan kepada siswa. Berdasarkan hasil dari uji-t pengaruh siswa terhadap produk yang digunakan $13,32 \%$.

Ketuntasan Belajar Klasikal

Ketuntasan belajar klasikal dinyatakan berhasil karena presentase siswa yang tuntas atau nilai lebih besar atau sama dengan $75 \%$ sebanyak 27 orang dan yang mendapat kurang dari $75 \%$ sebanyak 5 orang sehingga ketuntasan belajar klasikal diperoleh mencapai 84,37\%

Persentase hasil perhitungan pemahaman siswa tiap indikator sebelum menggunakan PosBuk (Poster Buku) dan setelah menggunakan PosBuk (Poster Buku) dapat dilihat pada grafik berikut ini:

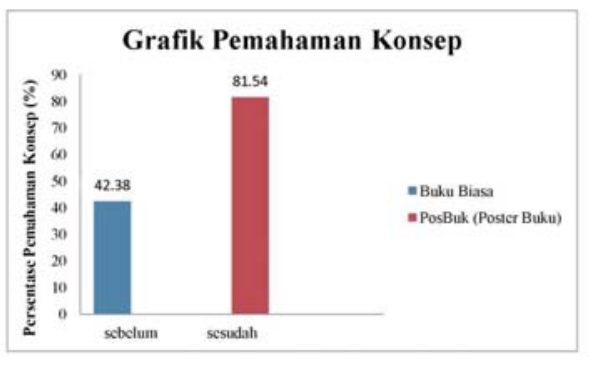

Grafik 4.5 Persentase pemahaman konsep Siswa Setiap Indikator Sebelum dan sesudah penggunaan PosBuk (Poster Buku).

Hasil perhitungan pemahaman konsep belajar siswa secara jelas dapat dilihat pada lampiran 14. Peningkatan pemahaman konsep belajar siswa juga harus dilihat secara klasikal. Dari hasil perhitungan dengan konversi data, diperoleh pemahaman peserta didik.

\section{SIMPULAN DAN SARAN Simpulan}

Berdasarkan penelitian yang telah dilaksanakan dapat di simpulkan bahwa media pembelajaran berupa PosBuk (Poster Buku) dapat:

1. Teruji kevalidannya baik dari segi ahli media maupun materi, dimana untuk kriteria pendidikan satu ahli memberikan nilai $A$ dan 3 ahli memberikan $B$, untuk kriteria tampilan 2 ahli memberikan nilai $A$ dan nilai $B$ dari 2 ahli yang lain, serta untuk kriteria teknis 4 ahli memberikan nilai $\mathrm{B}$.

2. Kepraktisan media pembelajaran sangat berguna bagi siswa, sehingga proses pembelajaran berjalan dengan lancar, karena respon siswa yang baik terhadap PosBuk (Poster Buku) yang menjadi sumber belajar.

3. Teruji keefektifannya karena mampu meningkatkan pemahaman konsep belajar siswa kelas $X$ iis unggulan MAN 1 Mataram pada materi Hukum Newton. Dimana diperoleh PosBuk (Poster buku) sebelum menggunakan media yaitu 42,38 dan setelah menggunakan media 81,54 jadi untuk gain pemahaman konsep 0,679. Sedangkan secara klasikal juga berada di atas $84,37 \%$ serta dari nilai Uji-t mendapatkan hasil 13,32.

\section{Saran}

Berdasarkan penelitiaan yang telah dilakukan, maka diberikan beberapa saran bagi peneliti selanjutnya yaitu:

1. PosBuk (Poster Buku) yang dikembangkan dapat digunakan dengan baik, namun masih memiliki kekurangan baik dari segi pendidikan, tampilan, dan kualitas teknis. Hal ini dapat dijadikan pertimbangan bagi peneliti selanjutnya untuk mengembangkan media pembelajaran yang lebih sempurna lagi.

2. PosBuk (Poster Buku) ini dapat dikembangkan untuk semua materi Fisika untuk materi yang berbeda.

3. Penelitian ini dilaksanakan sampai pada tahap uji coba kelompok kecil. Oleh karena itu diharapkan pada penelitian selanjutnya dilaksanakan sampai pada tahap penyebaran. 


\section{DAFTAR PUSTAKA}

Alek dan H. Achmad. 2011. Bahasa Indonesia Untuk Perguruan Tinggi. Jakarta: Kencana.

Ali, M. 2013. Pendidikan Kependidikan Prosedur \& Strategi. Bandung: CV. Angkasa.

Arikunto, S. 2006. Prosedur Penelitian Suatu Pendekatan Praktek. Jakarta: Rineka Cipta.

Arikunto, S. 2015. Dasar-Dasar Evaluasi Pendidikan. Jakarta: PT. Bumi Aksara

Arsyad, A. 2015. Media Pembelajaran Edisi Revisi. Jakarta: Rajawali Pers

Azwar, S. 2015. Tes Prestasi. Yogyakarta: Pustaka Pelajar

Citra, Y. 2012. Belajar dan Pembelajaran.Jakarta: PT. Bumi Aksara

Daryanto. 2010. Media Pembelajaran. Bandung: PT. Sarana Tutorial Nurani Sejahtera.

Emzir. 2014. Metode Penelitian Pendidikan Kuantitatif \& Kualitatif Edisi Revisi. Jakarta: PT Raja Grafindo Persada

Faizah, Atina Nur. 2014. Pengembangan Handout Fisika Berbasis Guided Note Taking Guna Meningkatkan Motivasi Belajar Siswa Kelas X Di SMA Negeri 3 Purwerejo Tahun Pelajaran 2013/2014. Radiasi Vol. 5 No. 2 September 2014. Diakses pada tanggal 06 Desember 2016 dari http://ejournal.umpwr.ac. id/ index.hp/radiasi/article/dowload/1 710/1625.

Hake, R.R. (1998). Interactive-engagement versustraditional methods: $A$ sixthousand-student survey of mechanics test data for introductory physics courses. American Journal of Physics 66, 64 (1998). 10.1119/1.18809

Hamdu, Ghullam dan Lisa Agustina. Pengaruh Motivasi belajar Siswa Terhadap Pestasi Belajar IPA Di Sekolah Dasar. Jurnal Penelitian Pendidikan Vol. 12 No. 1, April 2011: ISSN 1412-565X. Di akses pada tanggal 20 januari 2017

Jannah, Zahara F, dkk.2016. Pengembangan Media Pembelajaran Poster Fisika Fluida Statis Berbasis Lingkungan
Dalam bentuk Poster Photoscrap. Jurnal Prosiding Seminar Nasional Fisika (E-Journal), VOLUME V, OKTOBER 2016 pISSN: 2339-0654 e-ISSN: 24769398 dari http://snfunj.ac.id/kumpulan-prosiding /snf2016/. Di akses pada tanggal 20 januari 2017

Maiyena, S. 2013. Pengembangan Media poster berbasis pendidikan karakter untuk materi global warning. Jurnal Pendidikan, Volome 3 nomor 12013 ISSN :2089-6158. Di akses pada tanggal 06 Desember 2016

Mariati, P.S. 2012. Pengembangan Model Pembelajaran Fisika Berbasis Problem Solving Untuk Meningkatkan Kemampuan Metakognisi Dan Pemahaman Konsep Mahasiswa. Jurnal Pendidikan Fisika Indonesia 8 (2012) 152-160 ISSN: 1693-1246. Di akses pada tanggal 01 Mei 2017

Muhaimin A, dkk. 2015. Pengembangan Media Kapasitor Dan Pengaruhnya Terhadap Pemahaman Konsep Dan Sikap Ilmiah Siswa. Jurnal pendidikan Fisika Indonesia p-ISSN: 16931246 e-ISSN: 2355-3812 Januari 2015. Di akses pada tanggal 01 Mei 2017

Murdaka, Bambang. 2009. Fisika Dasar. Jogjakarta: CV. Andi OFFSET

Novitasari, Erma, dkk. 2013 Pengembangan Media Pembelajaran Berbasis It Berbentuk Permainan Ular Tangga Materi Alat Optik Untuk Kelas Vii Smp. Jurnal Pendidikan Fisika (2013) Vol. 1 No.1. Di akses pada tanggal 20 januari 2017 dari http://jurnal.fkip.uns.ac.id/index. php/pfisika/article/dowload/3728/2 611

Salmina, Mik \& Adyansyah, Fadlillah. 2017. Analisis kualitas soal ujian Matematika Semesrter Genap Kelas XI SMA Inshafudin Kota Banda Aceh. ISSN 2355-0074. Vol 4. No 1 
Sadirman, A, M. 2016.Interaksi dan Motivasi Belajar Mengajar. Jakarta: PT Rajagrafindo, Persada.

Sampudi A \& Morik.2009.Penggunaan Alat Peraga Papan Optic Untuk Meningkatkan Hasil Belajar Pemantulan Cahaya Pada Siswa VII.Jurnal Pendidikan Fisika Indonesia.ISSN 1693-1264.

Sudjana, Nana. 2014. Penelitian dan penilaian pendidikan. Bandung: Sinar Baru Algensindo.

Sugiyono. 2014. Metode Penelitian Kuantitatif Kualitatif dan $R \& D$. Bandung: Alfabeta. 